\title{
Effects of finfish aquaculture on biogeochemistry and bacterial communities associated with sulfur cycles in highly sulfidic sediments
}

\author{
Ayeon Choi ${ }^{1}$, Hyeyoun Cho ${ }^{1}$, Bomina Kim ${ }^{1}$, Hyung Chul Kim ${ }^{2}$, Rae-Hong Jung ${ }^{2}$, \\ Won-Chan Lee ${ }^{2}$, Jung-Ho Hyun ${ }^{1, *}$ \\ ${ }^{1}$ Department of Marine Science and Convergent Technology, Hanyang University, 55 Hanyangdaehak-ro, Sangnok-gu, \\ Ansan, Gyeonggi-do 15588, Republic of Korea \\ ${ }^{2}$ Marine Environment Research Division, National Institute of Fisheries Science (NIFS), Busan 46083, Republic of Korea
}

\begin{abstract}
A combination of biogeochemical analyses and molecular microbiological analyses were conducted to assess the environmental impact of finfish aquaculture and to elucidate the major microbial assemblages responsible for the production and removal of reduced sulfur compounds in fish-farm sediments. The average concentrations of $\mathrm{H}_{2} \mathrm{~S}(123 \mu \mathrm{M})$ and $\mathrm{NH}_{4}{ }^{+}(1310 \mu \mathrm{M})$

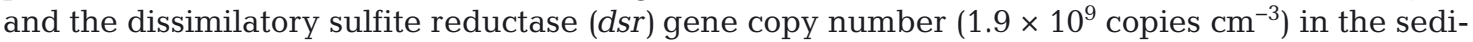
ments at the farm site were 15-, 1.5- and 2-fold higher, respectively, than those measured at the less-impacted reference site. Accordingly, the sulfate reduction rate (SRR) at the farm site $\left(118 \mathrm{mmol} \mathrm{m}^{-2} \mathrm{~d}^{-1}\right)$ was 19 -fold higher than that measured at the reference site $\left(6.2 \mathrm{mmol} \mathrm{m}^{-2} \mathrm{~d}^{-1}\right)$. Analyses of $d s r A$ and 16S rRNA gene sequences revealed that the Syntrophobacteraceae and Desulfobulbaceae groups are the major sulfate-reducing bacteria around the fish-farm sediment. Interestingly, despite the high SRR $\left(12.2-19.6 \mathrm{mmol} \mathrm{m}^{-2} \mathrm{~d}^{-1}\right)$, the $\mathrm{H}_{2} \mathrm{~S}$ concentration was low $(<8 \mu \mathrm{M})$ in the top $0-2 \mathrm{~cm}$ of the fish-farm sediments. In this sulfide-mismatched zone, sulfur-oxidizing bacteria associated with Gamma- and Epsilonproteobacteria were abundant. Especially at the 1-2 cm depth, bacteria related to Sulfurovum in the Epsilonproteobacteria showed the highest relative abundance, comprising $62 \%$ of the $16 \mathrm{~S}$ rDNA sequences. The results strongly suggest that Sulfurovum-like bacteria play a significant ecological and biogeochemical role in oxidation and reduction of reduced sulfur compounds from the organic-rich, highly sulfidic fish-farm sediments.
\end{abstract}

KEY WORDS: Aquaculture impacts · Benthic metabolism - Sulphidic environment - Sulfate reduction $\cdot$ Sulfate-reducing bacteria $\cdot$ Sulfur-oxidizing bacteria $\cdot$ Sulfurovum

\section{INTRODUCTION}

The global production of aquaculture, including finfishes, crustaceans, mollusks and other aquatic animals, increased from 2.6 million $\mathrm{t}$ in 1970 to 66.6 million $\mathrm{t}$ in 2012 (FAO 2010, 2014). Accordingly, the contribution of aquaculture to total global fisheries production doubled from $22.2 \%$ in 1996 to $42.2 \%$ in 2012 (FAO 2010, 2014). Although aquaculture provides a stable, high-quality food source for humans, large-scale industrial aquaculture activities inevitably cause severe environmental concerns by releasing

${ }^{*}$ Corresponding author: hyunjh@hanyang.ac.kr large quantities of organic materials, such as uneaten fish feed and fecal pellets, to the surrounding coastal areas (Gray et al. 2002, Brooks \& Mahnken 2003, Holmer et al. 2005, Kutti et al. 2007).

In organic-rich coastal sediments, oxygen is depleted quickly within a few $\mathrm{mm}$ of the surface sediment, and organic carbon $\left(\mathrm{C}_{\text {org }}\right)$ oxidation is dominated by anaerobic microorganisms relying on different terminal electron-accepting processes, such as denitrification and reduction of $\mathrm{Mn}(\mathrm{IV}), \mathrm{Fe}(\mathrm{III})$ and sulfate (Canfield et al. 2005). Because of the abundance of sulfate in seawater, sulfate reduction is

(C) The authors 2018. Open Access under Creative Commons by Attribution Licence. Use, distribution and reproduction are unrestricted. Authors and original publication must be credited. 
regarded as the predominant $\mathrm{C}_{\text {org }}$ oxidation pathway in coastal sediments, especially in organic-enriched fish-farm sediments (Holmer et al. 2005, Hyun et al. 2013). Major environmental concerns regarding the dominance of $\mathrm{C}_{\text {org }}$ oxidation resulting from sulfate reduction in fish-farm sediments include the accumulation of highly toxic, reactive hydrogen sulfide $\left(\mathrm{H}_{2} \mathrm{~S}\right)$, which affects the diversity and community structure of the benthic macrofaunal and microbial communities (Lee et al. 2004, Bissett et al. 2006, Heilskov et al. 2006, Kutti et al. 2007, Castine et al. 2009, Kawahara et al. 2009, Yoon et al. 2009, Hargrave 2010, Valdemarsen et al. 2015, Jung et al. 2016).

Because large-scale aquaculture has such a large effect on sediment biogeochemistry and coastal ecosystems via benthic-pelagic coupling (Holmer et al. 2005, Strain \& Hargrave 2005, Lee et al. 2011, Hyun et al. 2013), it is important to develop a tool to assess the environmental conditions of fish-farm sediments (MOF 2016). Total organic carbon content and concentrations of acid volatile sulfur compounds in the sediments have been proposed as chemical indicators for monitoring the environmental changes caused by fish farms and for evaluating farming capacity (Yokoyama 2003, Cho et al. 2013, Jung et al. 2016). However, the environmental assessment of fish-farm sediments relying solely on sulfur compounds is not useful for identifying major biogeochemical processes because these compounds are quickly recycled within the sediments (Canfield et al. 2005, Hyun et al. 2013, NIFS 2013). Additionally, biological indicators have been proposed for monitoring the environmental changes resulting from aquaculture. For example, changes of benthic macrofauna assemblages are generally recommended as a proxy for monitoring the impacts of cage farming (Macleod et al. 2008, Yoon et al. 2009, Jung et al. 2016). However, investigation of the benthic community using video surveillance and the identification of macrofauna and meiofauna to the level of individual species is expensive and requires professional skill to make an accurate assessment of the impact (Castine et al. 2009).

Alternatively, because bacterial communities respond quickly to environmental changes (Bissett et al. 2006, Castine et al. 2009, Kawahara et al. 2009), quantitative and qualitative analyses of the spatial distribution and metabolic activities of major microbial indicators may provide crucial information on the major $\mathrm{C}_{\text {org }}$ oxidation pathways and subsequent biogeochemical conversion of specific compounds that would be veiled by geochemical analysis alone (Vezzulli et al. 2002, Jørgensen 2006, Kondo et al. 2012a,b). However, little is known about the microorganisms directly responsible for the biogeochemical sulfur cycles in fish-farm sediments, where rapid recycling of sulfur compounds occurs (Asami et al. 2005, Bissett et al. 2006, Kondo et al. 2012a,b). The main objectives of this study were (1) to assess the environmental impact of finfish aquaculture in the sediments and (2) to elucidate microbial assemblages closely related to the production and removal of reduced sulfur from the surface sediments of a fish farm.

\section{MATERIALS AND METHODS}

\section{Study area}

The study area was located in Gamak Bay, a semienclosed bay near Yeosu on the southern coast of the Korean Peninsula (Fig. 1), where the aquaculture industry is heavily developed. In the study area, 2 main fish species, rockfish Sebastes schlegeli and sea bream Pagrus major, are cultured for 1.5 to $2 \mathrm{yr}$ before they are harvested after October. To improve the commercial value of the farmed fish before shipment, a large quantity of fish food is distributed just before harvest (NIFS 2007). Sediment samples were collected on 15 September 2010, when the sediments received a high organic load from uneaten feed and fecal pellets. Two sampling sites were chosen: one directly underneath the fish cages (hereafter the farm site), and another frontward of the water flow located $\sim 50 \mathrm{~m}$ in front of the fish cages (hereafter the reference site) to reduce direct impact by uneaten feed or fecal pellets (Fig. 1). Water depth was approximately 4 and $8.5 \mathrm{~m}$ at the farm and reference sites, respectively. The bottom water temperature and salinity were $24^{\circ} \mathrm{C}$ and $30.1 \mathrm{psu}$, respectively, at both sites. Dissolved oxygen (DO) concentration in the bottom water was $6.16 \mathrm{mg} \mathrm{l}^{-1}$ at both sites (NIFS 2010). Surface sediments at both sites were composed mostly of silt- and clay-sized sediment (NIFS 2010). Capitella capitata, a macrofaunal indicator of highly sulfidic conditions, was observed in the surface sediments of the farm site (NIFS 2010).

\section{Sampling and handling}

Sediment samples were taken before feeding to avoid disturbing the sediment condition. Triplicate sub-samples were collected for geochemical analyses using polycarbonate cores $(6.5 \mathrm{~cm}$ i.d., $25 \mathrm{~cm}$ long) by SCUBA divers to minimize sediment distur- 

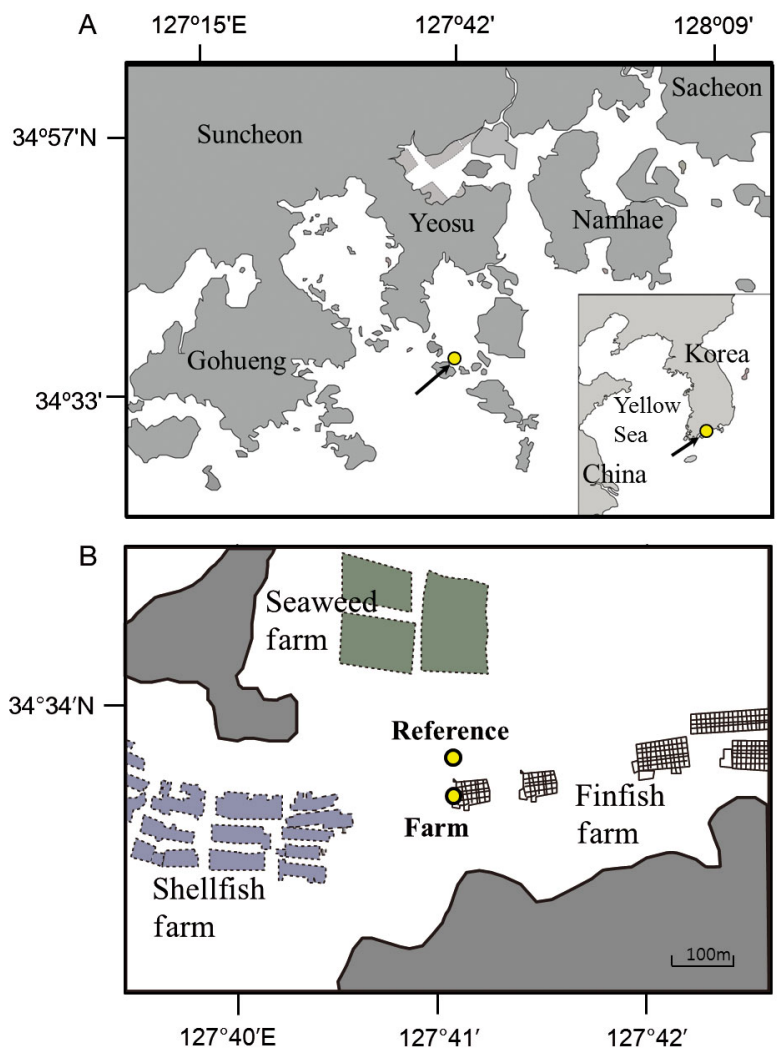

Fig. 1. (A) Study area in the coastal waters near Yeosu, South Korea; (B) 'farm' indicates the sampling site where sediment samples were taken directly underneath the fish cages, whereas 'reference' denotes the sampling site located $\sim 50 \mathrm{~m}$ away from the fish cages

bance during sampling activities. In the $\mathrm{N}_{2}$-filled plastic glove bag, the sediment core was sectioned into $1 \mathrm{~cm}$ intervals from the top of the core to a depth of $6 \mathrm{~cm}$ and at $2 \mathrm{~cm}$ intervals from $6 \mathrm{~cm}$ to $10 \mathrm{~cm}$ in depth. The sediments were then transferred to sterile centrifuge tubes (BD). The tubes were tightly capped and centrifuged for $10 \mathrm{~min}$ at $2700 \times \mathrm{g}$. After reintroduction into the glove bag, porewater was sampled and filtered through $0.2 \mu \mathrm{m}$ cellulose ester syringe filters (ADVANTEC). Duplicate samples of surface sediment $(0-2 \mathrm{~cm})$ for measuring particulate organic carbon (POC) and total nitrogen (TN) were frozen at $-20^{\circ} \mathrm{C}$ until processed in the laboratory. Surface sediments for DNA extraction were collected using plastic cores that were pre-washed with sterilized water, rinsed with $70 \%$ ethanol and then stored at $-80^{\circ} \mathrm{C}$ until analysis.

\section{Porewater and solid-phase analyses}

$\mathrm{NH}_{4}{ }^{+}, \mathrm{NO}_{3}{ }^{-}$and $\mathrm{PO}_{4}{ }^{3-}$ concentrations in porewater were analyzed using an autoanalyzer (Proxima,
Alliance; Hansen \& Koroleff 1999). Dissolved sulfide was determined spectrophotometrically using the methylene blue method (Cline 1969) after precipitating sulfide in the filtered porewater with $\mathrm{Zn}$ acetate $(20 \%) . \mathrm{SO}_{4}{ }^{2-}$ concentration was measured in acidified porewater using ion chromatography (Metrohm 761). Dissolved $\mathrm{Fe}^{2+}$ was determined by the colorimetric method with Ferrozine (Stookey 1970). The detection limits of $\mathrm{NH}_{4}{ }^{+}, \mathrm{NO}_{3}{ }^{-}, \mathrm{PO}_{4}{ }^{3-}, \mathrm{H}_{2} \mathrm{~S}$ and $\mathrm{Fe}^{2+}$ were $0.021,0.006,0.007,3$ and $1 \mu \mathrm{M}$, respectively. The acetic acid concentration in porewater was analyzed using HPLC (Dionex Ultimate 2000).

Total oxalate-extractable $\mathrm{Fe}$ (hereafter total $\mathrm{Fe}_{\text {(oxal) }}$ ) was extracted according to Thamdrup \& Canfield (1996). Oxalate-extractable Fe(II) (hereafter Fe(II) $)_{\text {(oxal) }}$ ) was extracted from frozen sediment in anoxic oxalate solution (Phillips \& Lovley 1987). Both total $\mathrm{Fe}_{\text {(oxal) }}$ and $\mathrm{Fe}(\mathrm{II})_{\text {(oxal) }}$ were determined as described for the porewater analysis of $\mathrm{Fe}^{2+}$. Oxalate-extractable Fe(III) (hereafter $\left.\mathrm{Fe}(\mathrm{III})_{\text {(oxal) }}\right)$ was defined as the difference between the total $\mathrm{Fe}_{\text {(oxal) }}$ and $\mathrm{Fe}(\mathrm{II})_{\text {(oxal) }}$. POC and TN content were determined using a CHN analyzer (EA 1110; CE Instruments, Milan, Italy). The POC samples were treated with $\mathrm{HCl}(10 \%)$ to remove $\mathrm{CaCO}_{3}$.

\section{Rate of sulfate reduction}

The microbial sulfate reduction rates (SRR) were determined in triplicate from intact cores $(3 \mathrm{~cm}$ i.d., $35 \mathrm{~cm}$ long) according to the radiotracer $\left({ }^{35} \mathrm{~S}_{-} \mathrm{SO}_{4}{ }^{2-}\right.$, $15 \mathrm{kBq} \mathrm{ll}^{-1}$, Institute of Isotopes) method of Jørgensen (1978). Five microliters of the ${ }^{35} \mathrm{~S}-\mathrm{SO} 4{ }^{2-}$ working stock solution were injected into the sediment cores at $1 \mathrm{~cm}$ intervals. After $2 \mathrm{~h}$ of incubation at in situ temperature, the sediment was sliced into sections and then fixed in $\mathrm{Zn}$ acetate $(20 \%)$ before being frozen immediately. Reduced ${ }^{35} \mathrm{~S}$ extraction was performed using the 1-step distillation method (Fossing \& Jørgensen 1989).

\section{Nucleic acid extraction and quantification of the $d s r$ gene}

Total DNA was extracted using a PowerSoil DNA Isolation Kit (Mo Bio Laboratories) following the manufacturer's instructions. A quantitative PCR (qPCR) was used to determine copy numbers of the alpha subunit of the dissimilatory (bi)sulfite reductase gene $(d s r A)$. The copy number of $d s r A$ was used to quantify sulfate-reducing prokaryotes and was 
determined using SYBR Green I assays, as described previously (Kondo et al. 2004, 2008, Liu et al. 2009). The primers DSR $1 \mathrm{~F}\left(5^{\prime}\right.$-ACS CAC TGG AAR CAC G-3') (Wagner et al. 1998) and DSR R (5'-GTG GMR CCG TGC AKR TTG G-3') (Kondo et al. 2004) were used to amplify the $d s r A$ gene. The amplicon size was 220 bp. The SYBR Green I assay was always performed with a melting curve analysis to check PCR specificity. qPCR was performed on an ABI 7500 Real Time PCR system (Applied Biosystems) as follows: an initial incubation step for $2 \mathrm{~min}$ at $50^{\circ} \mathrm{C}$ (activation of the polymerase) followed by a 10 min pre-denaturation step at $95^{\circ} \mathrm{C}$, and 40 cycles of denaturation for $30 \mathrm{~s}$ at $95^{\circ} \mathrm{C}$ and annealing for $1 \mathrm{~min}$ at $60^{\circ} \mathrm{C}$. The PCR products from the environmental dsrA gene clones were ligated into pGEM TEasy vector (Promega) and then used as the standard DNA for the dsr gene quantification (Cho et al. 2017).

\section{Diversity of 16S rRNA genes and the dsr gene}

The bacterial 16S rRNA genes obtained from the sediment samples collected at the $0-1 \mathrm{~cm}$ and $1-2 \mathrm{~cm}$ depths of the farm and reference sites were amplified using the primers 27F (5'-AGA GTT TGA TCC TGG CTC AG-3') (Rho et al. 2005) and 1518R (5'-AAG GAG GTG ATC CAN CCR CA-3') (Campbell et al. 2001) as described by Cho et al. (2017).

A $\sim 1.9 \mathrm{~kb}$ dsrAB gene fragment obtained from the 1 to $2 \mathrm{~cm}$ depth of the sediments was amplified according to previously described PCR method (Harrison et al. 2009, Cho et al. 2017) using primers DSR1F (5'-ACS CAC TGG AAR CAC G-3') (Wagner et al. 1998) and DSR4R-1 (5'-GTT ACC GCA RAA CAT RCA-3').

PCR products were purified using the MEGAquick-spin ${ }^{\mathrm{TM}}$ fragment DNA Purification kit (iNtRON Biotechnology). The purified PCR amplicons were ligated into the pGEM-T Easy vector (Promega) and transformed into Escherichia coli DH5 $\alpha$ cells. The insert DNA in the pGEM-T Easy vector was amplified using the primers M13F (-20) (5'- GTA AAA CGA CGG CCA G-3') and M13R (-20) (5'-CAG GAA ACA GCT ATG AC-3'). All sequences obtained from SolGent (Daejeon, Korea) were checked for chimeric artifacts using the Pintail program of the Bioinformatics Toolkit (Ashelford et al. 2005). These sequences were aligned with closely related sequences obtained from GenBank (www.ncbi.nlm.nih.gov/BLAST) using ClustalW in MEGA 4.0. The filtered 16S rRNA and $d s r A$ sequences that shared $>97 \%$ similarity were grouped in the same operational taxonomic unit (OTU). Phylogenetic trees were constructed using the neighbor-joining method with the Jukes and Cantor distance model, implemented within MEGA 4.0. Node support was assessed by bootstrapping using 1000 bootstrap replicates.

\section{Nucleotide sequence accession number}

The bacterial 16S rRNA and $\operatorname{dsr} A$ sequences obtained in this study were deposited in the NCBI GenBank database under accession numbers KC631436 to KC631612 for the bacterial 16S rRNA gene related to Epsilonproteobacteria and MH071538 to MH071597 for the dsrA gene.

\section{Statistical analysis}

The rarefraction analyses of partial sequences of 16S rRNA and $d s r$ were calculated using the MOTHUR program (Fig. S1 in the Supplement at www.int-res.com/articles/suppl/q010p413_supp.pdf; Schloss et al. 2009). To compare the difference of means for geochemical properties, POC, TN, SRR and the abundance of $d s r$ A gene copy number, Student's $t$-test was used. Before analysis, the homogeneity of variance was checked using Levene's test.

\section{RESULTS}

\section{Geochemical parameters}

In the sediment trap, the suspended particulate matter (SPM), POC and TN at the farm site were $\sim 2$-fold higher than those of the reference site (Table 1). The POC and TN contents in the sediments and the acetic acid concentration in the porewater at the farm site were higher than those measured at the reference site, although the difference between the 2 sites was not significant $(\mathrm{p}=0.076, \mathrm{p}=0.096$ and $\mathrm{p}=$ 0.149 , respectively, Table 1 ). The vertical profile of $\mathrm{NH}_{4}{ }^{+}$in porewater increased with depth to $1424 \mu \mathrm{M}$ at the farm site and to $1133 \mu \mathrm{M}$ at the reference site (Fig. 2A). The average concentration of $\mathrm{NH}_{4}{ }^{+}$down to $10 \mathrm{~cm}$ depth was 1.5-fold higher at the farm $(1310 \mu \mathrm{M})$ than at the reference site $(890 \mu \mathrm{M})$ (Table 2). $\mathrm{NO}_{3}{ }^{-}$concentrations were $5.2 \mu \mathrm{M}$ and $3.8 \mu \mathrm{M}$ at the sediment-water interface of the farm and reference sites, respectively, and decreased with depth to $<2.4 \mu \mathrm{M}$ at both sites (Fig. 2B). $\mathrm{PO}_{4}{ }^{3-}$ concentration ranged from 7.70 to $17.56 \mu \mathrm{M}$ at the 


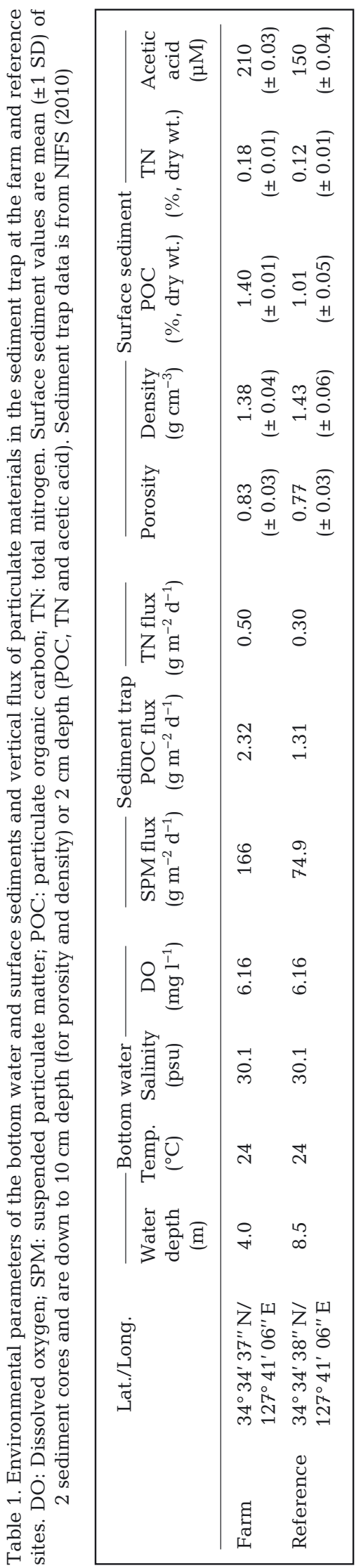

farm site and from 0.87 to $6.89 \mu \mathrm{M}$ at the reference site (Fig. 2C). The average concentration of $\mathrm{PO}_{4}{ }^{3-}$ was 3 -fold higher at the farm site $(10.74 \mu \mathrm{M})$ than at the reference site $(3.74 \mu \mathrm{M}) . \mathrm{H}_{2} \mathrm{~S}$ concentration in porewater was $<8 \mu \mathrm{M}$ down to $2 \mathrm{~cm}$ at the farm site but then rapidly increased with depth, reaching $394 \mu \mathrm{M}$ at $10 \mathrm{~cm}$, whereas the accumulation of $\mathrm{H}_{2} \mathrm{~S}$ was relatively indiscernible at the reference site (Fig. 2D). The average concentration of $\mathrm{H}_{2} \mathrm{~S}$ at the farm site $(123.6 \mu \mathrm{M})$ was 15 -fold higher than that at the reference site $(8.20 \mu \mathrm{M})$ (Table 2$). \mathrm{SO}_{4}{ }^{2-}$ concentrations were similar at both sites ( 24 mM) (Fig. 2E). $\mathrm{Fe}^{2+}$ concentration ranged from 1.4 to $10.4 \mu \mathrm{M}$ at the farm site and from 0.8 to $36.0 \mu \mathrm{M}$ at the reference site (Fig. 2F). The average concentration of $\mathrm{Fe}^{2+}$ at the farm site $(3.38 \mu \mathrm{M})$ was 6 -fold lower than that at the reference site $(20.31 \mu \mathrm{M})$. The average concentrations of $\mathrm{NH}_{4}{ }^{+}, \mathrm{PO}_{4}{ }^{3-}, \mathrm{HS}^{-}$and $\mathrm{Fe}^{2+}$ at the farm site were significantly different from those measured at the reference site $(p<0.0001, p=0.006, p=0.007$ and $\mathrm{p}<0.0001$, respectively), whereas the difference in concentrations of $\mathrm{NO}_{3}{ }^{-}$and $\mathrm{SO}_{4}{ }^{2-}$ between the 2 sites was not significant $(p=0.509$ and $p=0.077$, respectively).

The total $\mathrm{Fe}_{\text {(oxal) }}$ concentration ranged from 39.9 to $48.2 \mu \mathrm{mol} \mathrm{cm} \mathrm{cm}^{-3}$ at the farm site and from 40.4 to $45.7 \mu \mathrm{mol} \mathrm{cm} \mathrm{cm}^{-3}$ at the reference site (Fig. 2G,H). $\mathrm{Fe}(\mathrm{III})_{\text {(oxal) }}$ comprised $50-94 \%$ at the farm site and $50-$ $99 \%$ at the reference site (Fig. 2I). The average concentrations of $\mathrm{Fe}(\mathrm{II})_{\text {(oxal) }}$ and $\mathrm{Fe}(\mathrm{III})_{\text {(oxal) }}$ were similar at both the farm (17.39 Fe(II) $\mu \mathrm{mol} \mathrm{cm}{ }^{-3}$ and $26.58 \mathrm{Fe}$ (III) $\mu \mathrm{mol} \mathrm{cm}{ }^{-3}$ ) and reference sites (15.05 Fe(II) $\mu \mathrm{mol} \mathrm{\textrm {cm } ^ { - 3 }}$ and $28.16 \mathrm{Fe}(\mathrm{III}) \mu \mathrm{mol} \mathrm{cm}{ }^{-3}$ ) (Table 2). The concentrations of $\mathrm{Fe}(\mathrm{II})_{\text {(oxal) }}$ and $\mathrm{Fe}(\mathrm{III})_{\text {(oxal) }}$ were not significantly different between the farm and reference sites $(p=$ 0.082 and $p=0.157$, respectively). Average concentrations of total reduced sulfur (TRS) ranged from 71.4 to $259 \mu \mathrm{mol} \mathrm{cm} \mathrm{cm}^{-3}$ at the farm site and from 9.21 to $129 \mathrm{mmol} \mathrm{cm}^{-3}$ at the reference site (Fig. 2J), and the TRS concentration between the 2 sites was significantly different $(p=0.0005)$.

\section{SRR and dsr gene copy number}

SRR ranged from 753 to $1957 \mathrm{nmol} \mathrm{cm} \mathrm{cm}^{-3} \mathrm{~d}^{-1}$ at the farm site and from 22.1 to $77.0 \mathrm{nmol} \mathrm{cm}^{-3} \mathrm{~d}^{-1}$ at the reference site (Fig. 3A). Average SRR at the farm site $\left(1209 \mathrm{nmol} \mathrm{cm}^{-3} \mathrm{~d}^{-1}\right)$ was 19 -fold higher than that measured at the reference site $\left(62.1 \mathrm{nmol} \mathrm{cm}^{-3} \mathrm{~d}^{-1}\right)$. The abundance of $d s r$ gene copy number ranged from $1.1 \times 10^{9}$ to $3.4 \times 10^{9}$ copies $\mathrm{cm}^{-3}$ at the farm site and from $4.3 \times 10^{8}$ to $1.3 \times 10^{9}$ copies $\mathrm{cm}^{-3}$ at the ref- 

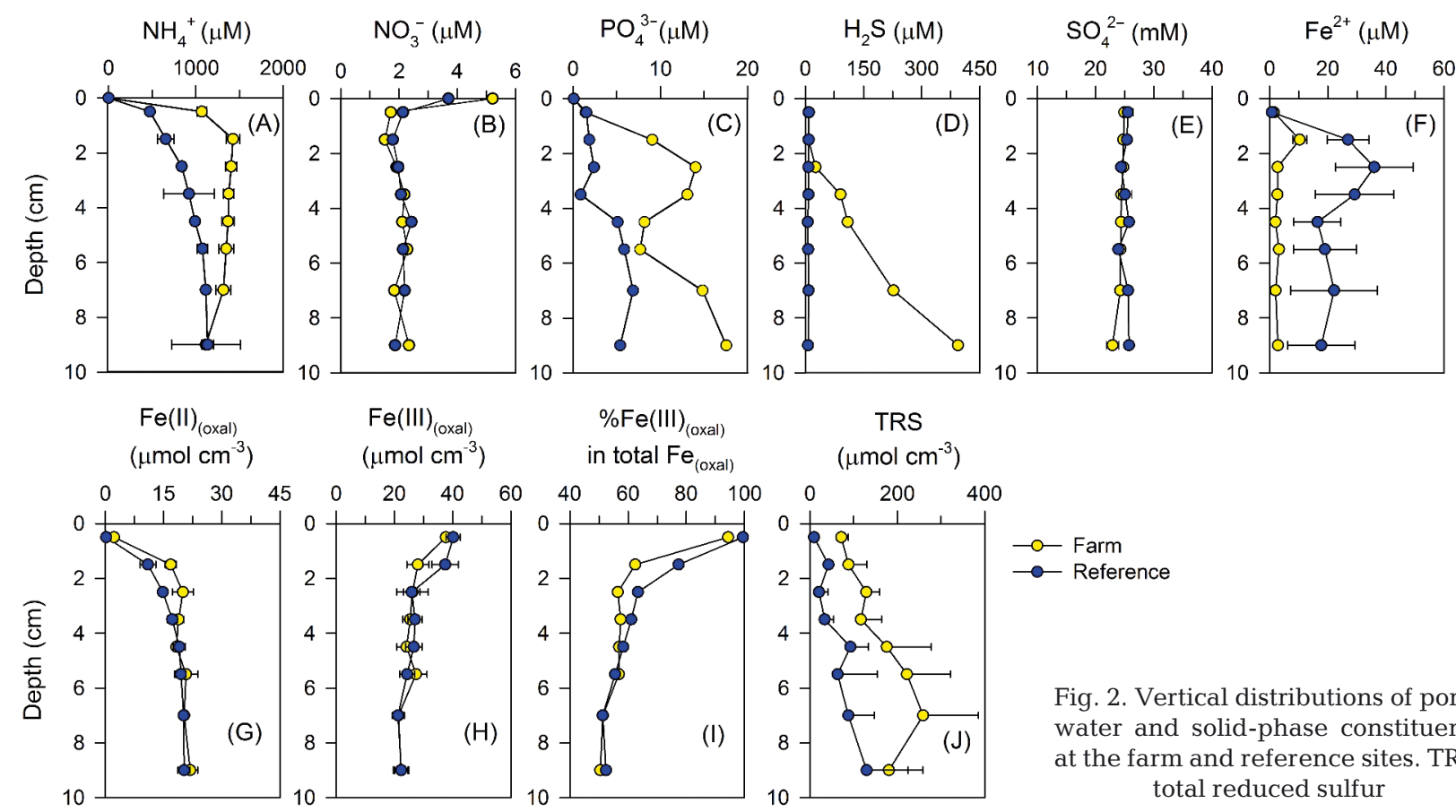

Fig. 2. Vertical distributions of porewater and solid-phase constituents at the farm and reference sites. TRS: total reduced sulfur

erence site (Fig. 3B). The peak of the $d s r$ gene copy number $\left(3.4 \times 10^{9}\right.$ copies $\left.\mathrm{cm}^{-3}\right)$ was observed at a depth of 1 to $2 \mathrm{~cm}$ where SRR was maximal (1958 $\mathrm{nmol} \mathrm{cm}^{-3} \mathrm{~d}^{-1}$ ). The SRR and the abundance of $d s r$ gene copy number were significantly different between the farm and reference sites $(p<0.0001$ and $\mathrm{p}=0.0001$, respectively).

\section{Bacterial community composition}

A total of 376 bacterial 16S rRNA gene sequences were analyzed to elucidate the major bacterial groups inhabiting the surface sediments at both sites. These sequences were assigned to 302 OTUs based on a $3 \%$ cutoff (Table S1 in the Supplement). The coverage rates of $16 \mathrm{~S}$ rRNA gene libraries were 11 and $9 \%$ at a depth of $0-1 \mathrm{~cm}$ at the farm and reference sites, respectively, and 59 and $8 \%$ at a depth of $1-2 \mathrm{~cm}$ at the farm and reference sites, respectively (Table S1). Rarefaction curves based on the 16S rRNA gene sequences were obtained by plotting with the observed OTUs for each library (Fig. S1), yet none reached the curvilinear or plateau phase at the species level (3\% difference) (Fig. S1). However, the underestimation of diversity at the family and order levels (10 and 16\% difference) was less significant since the curves came close to reaching a plateau. Most sequences ( $>50 \%$ of total $16 \mathrm{~S}$ rRNA gene sequences) were affiliated with the Alpha-, Gamma-, Delta- and Epsilonproteobacteria,
Acidobacteria and several minor groups including Actinobacteria, Armatimonadetes, Bacteroidetes, Betaproteobacteria, Chloroflexi, Cyanobacteria, Deferribacteres, Deinococcus, Firmicutes, Fusobacteria, Parcubacteria, Planctomycetes and Verrucomicrobia (see Fig. 6, Table S1). Major groups occupying $>15 \%$ of total 16S rRNA gene sequences were related to Gamma-, Delta- and Epsilonproteobacteria (Table 3).

In total, $114 d s r A$ gene sequences were obtained from the $1-2 \mathrm{~cm}$ depth interval and were sorted into 70 OTUs using our definition of $>97 \%$ sequence identity (Table S2). All $d s r A$ gene sequences were affiliated with bacteria, and no archeal $d s r A$ genes were detected. The coverage of the $d s r A$ gene libraries showed 35 and $43 \%$ at the farm and reference sites, respectively. Rarefaction curves based on $d s r A$ gene sequences at the farm and reference sites approached near saturation at the family level $(10 \%$ difference) (Fig. S1).

\section{Bacterial communities associated with sulfate reduction}

Sulfate-reducing bacteria (SRB) revealed by $16 \mathrm{~S}$ rRNA gene sequences were closely associated with Desulfarculaceae, Desulfobulbaceae, Desulfuromonadaceae and Syntrophobacteraceae in Deltaproteobacteria at both sites (Table 3). The relative abundance of SRB in Deltaproteobacteria comprised $11 \%$ (0-1 cm depth) and $6 \%(1-2 \mathrm{~cm}$ depth) of total $16 \mathrm{~S}$ 


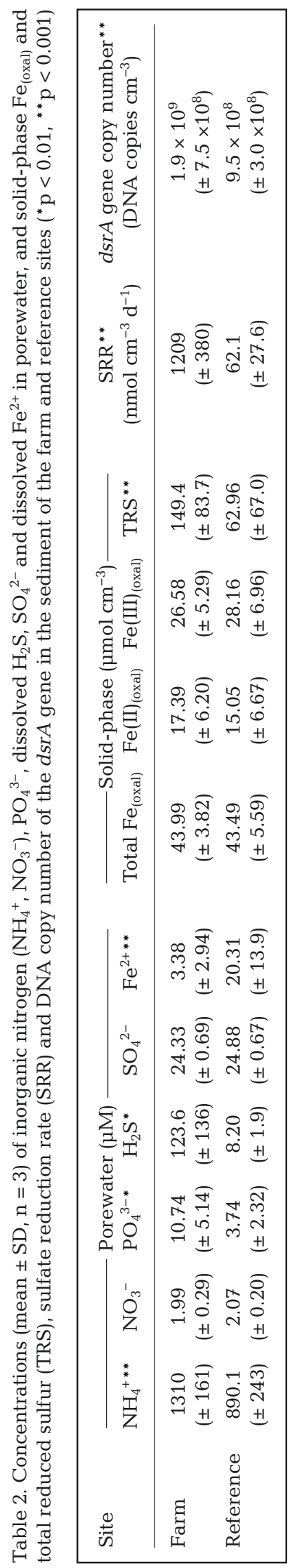

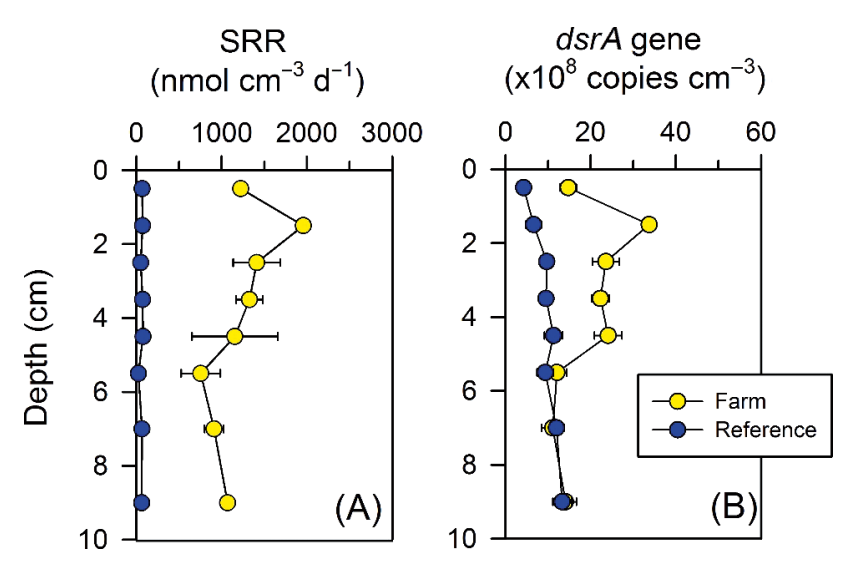

Fig. 3. Vertical distributions of (A) sulfate reduction rate (SRR) and (B) DNA copy number of the $d s r A$ gene at farm and reference sites

rRNA gene sequences at the farm site and $10 \%$ (0-1 cm depth) and $28 \%(1-2 \mathrm{~cm}$ depth) of total $16 \mathrm{~S}$ rRNA gene sequences at the reference site (Table 3). Particularly, Desulfobulbus (similarity > $95 \%$ ) in Desulfobulbaceae appeared as the major member at both sites (Table 3).

Based on the dsrA functional gene analysis, 5 different phylogenetic groups were clustered (Fig. 4). SRB affiliated with Syntrophobacteraceae (Group III) appeared to be the predominant bacterial group at the farm and reference sites, comprising 57 and $53 \%$ of the total clones, respectively (Fig. 4, Table S2). Most sequences of this group were related to uncultured Syntrophobacteraceae clones discovered from the Aarhus Bay (JQ304781 and JQ304763; de Rezende et al. 2013) (similarity > 95\%). However, they had low similarity (57-75\%) with the cultured isolates (Desulfacinum infernum, Desulforhabdus amnigena, Syntrophobacter wolinii, S. fumaroxidans and Thermodesulforhadus norvegica) (Fig. 4, Table S2).

The second dominant SRB group (Group V), comprising 23 and $33 \%$ of total $d s r A$ gene sequences at the farm and reference sites, respectively (Table S2), was not affiliated with any cultured SRB but clustered closely as a deep-branching lineage (Fig. 4). The deep-branching group in this study was associated with reported SRB lineage Group V encompassing Clone NTd-V07 (AB263178; Kaneko et al. 2007) (similarity $98 \%$ ) in Nankai Trough deep-sea sediment and the DSR-F group including Clones TopDsr2, TopDsr35, TopDsr59, TopDsr78, MidDsr71 and BotDsr73 (FJ748832-FJ748843; Jiang et al. 2009) (similarity > $87 \%$ ) in the Pearl River Estuary (Fig. 4, Table S2).

The next 2 minor groups, Group I and Group II, were closely related to Desulfobacteraceae and Desulfobulbaceae. The number of sequences affili- 
Table 3. Bacterial composition and number of clones closely related to Gamma-, Epsilon- and Deltaproteobacteria found at the farm and reference sites. Numbers in parentheses represent the relative abundance of each clone. The putative function of closely related species (only sequence similarities $>95 \%$ ) is indicated. Chem O: chemoorganotrophy; F: fermentation; FeR: Fe(III) reduction; NR: nitrate reduction; SO: sulfur oxidation; SR: sulfate reduction. The total number of clones is the total number of bacterial $16 \mathrm{~S}$ rRNA gene clones from Table S1

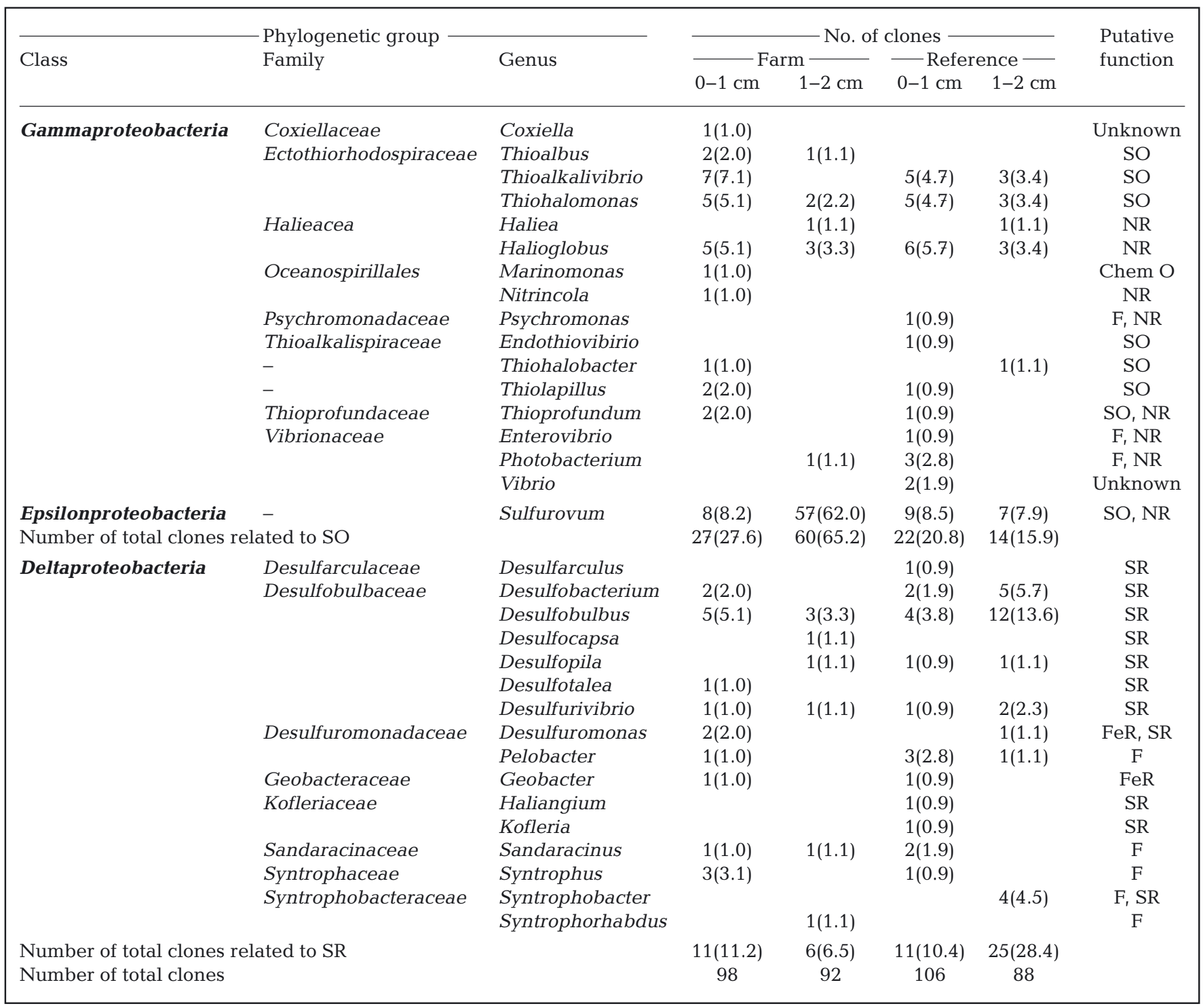

ated with Group I accounted for 11 and $6 \%$ of total $d s r A$ gene sequences at the farm and reference sites, respectively (Table S2). The sequences of Group I were associated with uncultured SRB bacterium clones detected from Aarhus Bay sediments (AM408827; Leloup et al. 2009, JQ304757; de Rezende et al. 2013) (similarity: 95\%), Mediterranean Sea oligotrophic waters (FM212289; Giloteaux et al. 2010) (similarity: $95 \%$ ) and Ulleung Basin sediments (JN798936; Cho et al. 2017) (similarity: 96\%). Only clone YF2_23 at the farm site was closely related to Desulfococcus multivorans, with a similarity of $97 \%$ (Table S2). The sequences of Group II accounted for $8 \%$ of total dsrA gene sequences at the reference site (Table S2). Most sequences of Group II were closely related to those of uncultured SRB found in environmental samples from sites such as Victoria Harbor in Hong Kong (DQ112190; Zhang et al. 2008) (similarity > 96\%) and a salt marsh on the east coast of the USA (KP992730; Angermeyer et al. 2016) (similarity: 90\%); both sites are affected by high organic material input via anthropogenic activities (Fig. 4). 


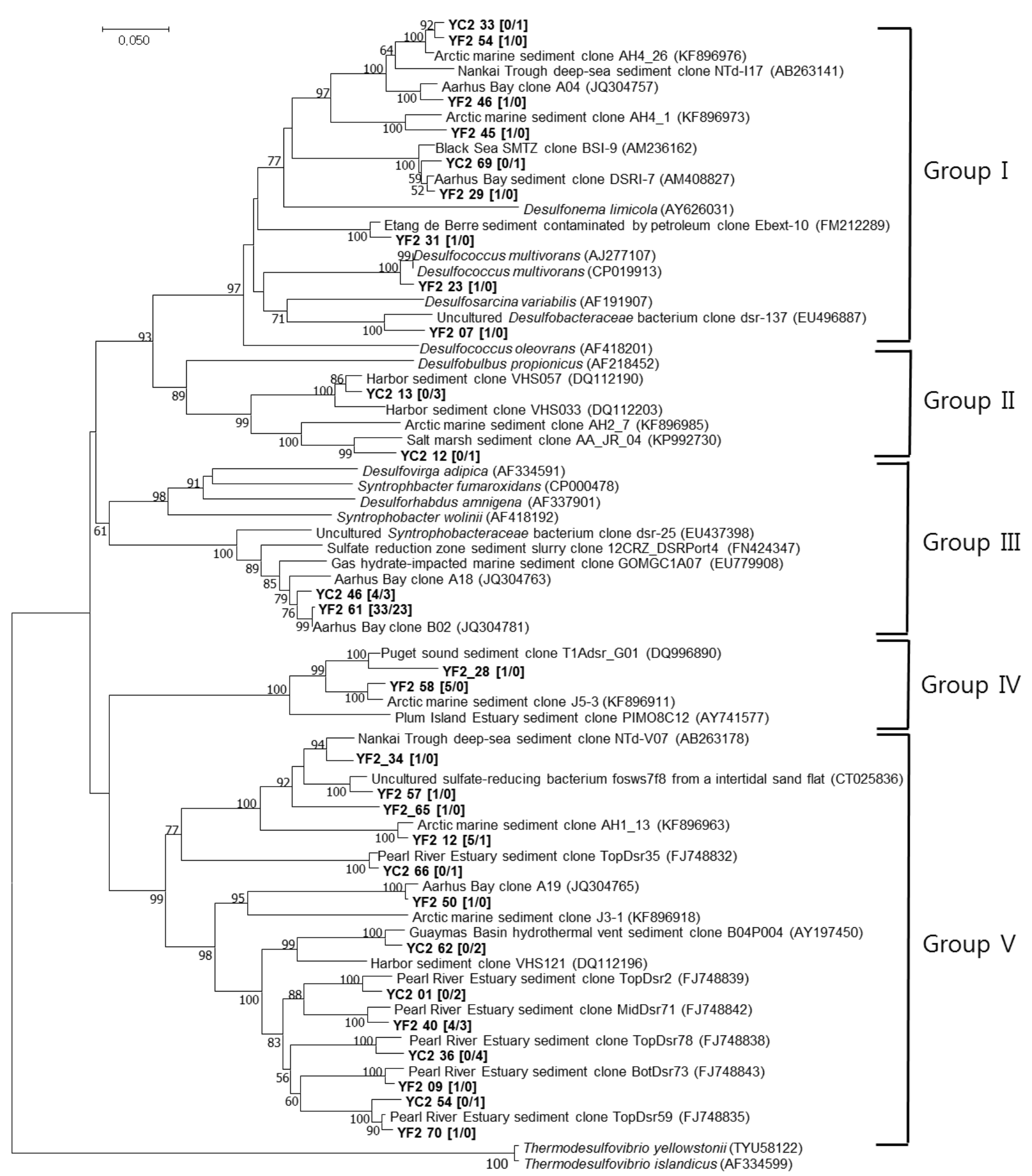

Fig. 4. Phylogenetic tree based on partial sequences of $d s r A$ from sulfate-reducing prokaryotes, including partial sequences based on environmental $d s r A$ gene amplicons. Sequences were retrieved from sediment $(1-2 \mathrm{~cm}$ depth) of the farm (YF) and reference (YC). The tree was constructed using the neighbor-joining method with Thermodesulfovibrio yellowstonii and T. islandicus. Bootstrap values are based on 1000 replicates and are indicated at branch nodes for values $>50 \%$ bootstrap support. Numbers in square brackets indicate the number of $d s r A$ gene sequences detected from YF and YC. GenBank accession numbers for each sequence are indicated in parentheses 


\section{Bacterial communities associated with sulfur oxidation}

As shown by the 16S rRNA gene sequencing, sulfur-oxidizing bacteria (SOB) were closely related to Gamma- and Epsilonproteobacteria (Table 3). The relative abundance of SOB affiliated with Gammaproteobacteria was $19 \%(0-1 \mathrm{~cm}$ depth) and $3 \%(1-$ $2 \mathrm{~cm}$ depth) of total sequences at the farm site, whereas they accounted for $12 \%(0-1 \mathrm{~cm}$ depth) and $8 \%(1-2 \mathrm{~cm}$ depth) of total sequences at the reference site (Table 3). Members such as Thioalbus, Thioalkalivibrio and Thiohalomonas belonging to the family Ectothiorhodospiraceae (similarity > 90\%) appeared as the dominant SOBs (Table 3). Known as denitrifying chemolithoautotrophic SOB, these bacteria have been isolated from various environments such as the East Sea, hydrothermal vents and hypersaline environments (Sorokin et al. 2001, Park et al. 2011, Nunoura et al. 2014).

Unlike the distribution of SOB related to Gammaproteobacteria, the relative abundance of the Epsilonproteobacteria in total clones increased dramatically from $8 \%$ at $0-1 \mathrm{~cm}$ depth to $62 \%$ at $1-2 \mathrm{~cm}$ depth at the farm site, while this group comprised $8 \%$ at both depths at the reference site (Table 3, Table S1). All sequences belonging to Epsilonproteobacteria were related to uncultured sequences detected in intertidal sediments (DQ112501), deepsea sediments with substantial organic loading (GQ 261802; Goffredi \& Orphan 2010), a deep-sea mud volcano (HQ588432; Pachiadaki et al. 2011) and mariculture sediments (JX193374; Li et al. 2013) with similarity $>93 \%$ (Fig. 5). The epsilonproteobacterial sequences were closely affiliated with Sulfurovum lithotrophicum (similarity $>95 \%$ ) and $S$. riftiae (similarity $>94 \%$ ), chemolithoautotrophs which use $\mathrm{S}^{0}$ or $\mathrm{S}_{2} \mathrm{O}_{3}{ }^{2}$ as an electron donor and $\mathrm{O}_{2}$ or $\mathrm{NO}_{3}{ }^{-}$as an electron acceptor (Inagaki et al. 2004, Giovannelli et al. 2016) (Fig. 5).

\section{DISCUSSION}

\section{Impact of the fish farm on sediment geochemistry and sulfur cycles}

The fish-farm sediments were characterized by highly reduced conditions with increased accumulation of $\mathrm{NH}_{4}{ }^{+}, \mathrm{PO}_{4}{ }^{3-}$ and $\mathrm{H}_{2} \mathrm{~S}$ (Fig. 2, Table 2) and extremely high SRR compared to measurements at the reference site (Fig. 3). The SRRs reported here were within the range (92 to $310 \mathrm{mmol} \mathrm{m}^{-2} \mathrm{~d}^{-1}$ ) reported from other organic-rich fish-farm sediments (Holmer \& Kristensen 1992, Holmer et al. 2003, 2005) but were markedly higher than those measured in shellfish farms (30-61 $\left.\mathrm{mmol} \mathrm{m}^{-2} \mathrm{~d}^{-1}\right)$, where no artificial fish feed is used (Dahlbäck \& Gunnarsson 1981, Holmer et al. 2003, Kim et al. 2011, Hyun et al. 2013).

The most intriguing geochemical property observed in the fish-farm sediment was the sulfide depletion at the 0 to $2 \mathrm{~cm}$ depth (Fig. 2D), where the highest SRR and $d s r$ gene abundance were also observed (Fig. 3). A combination of microbial $\mathrm{C}_{\text {org }}$ oxidation by $\mathrm{Fe}(\mathrm{III})$ reduction and abiotic reduction of Fe(III) coupled with S oxidation is responsible for this mismatch of sulfide (Thamdrup et al. 1993, Canfield et al. 2005). First, the amounts of Fe(III) (oxal) (28-37 $\mu \mathrm{mol} \mathrm{cm}{ }^{-3}$ ) appeared to be a major solid form of $\mathrm{Fe}_{(\text {oxal) }}$, comprising 60 to $95 \%$ of total $\mathrm{Fe}_{(\text {oxal })}$ at the 0-2 cm depth in the fish-farm sediments (Fig. $2 \mathrm{H}, \mathrm{I}$ ). The availability of $\mathrm{Fe}(\mathrm{III})_{\text {(oxal) }}$ ultimately stimulates microbial $\mathrm{C}_{\text {org }}$ oxidation coupled with $\mathrm{Fe}(\mathrm{III})$ reduction, thereby resulting in an accumulation of $\mathrm{Fe}^{2+}$ (Eq. 1; Canfield et al. 2005). Second, the Fe(III) (oxal) $_{1}$ in the sulfidic sediments is readily reduced by the sulfide to form $\mathrm{Fe}^{2+}$ and $\mathrm{S}^{0}$ in the sediment (Eq. 2; Canfield \& Thamdrup 1996). Both biotic and abiotic reduction of Fe(III) via Eqs. (1) and (2), respectively, should produce substantial amounts of $\mathrm{Fe}^{2+}$ in the surface sediment (Fig. 2F). Finally, at the farm site where sulfate reduction was high (Fig. 3A), the $\mathrm{Fe}^{2+}$ removed the sulfide to form FeS (Eq. 3; Canfield et al. 2005). Because the dissolved $\mathrm{Fe}^{2+}$ was highly depleted at the farm site (Fig. 2F), $\mathrm{H}_{2} \mathrm{~S}$ oxidation coupled with $\mathrm{Fe}^{2+}$ oxidation (Eq. 3) is likely to be higher at the farm site than at the reference site. Accordingly, average concentrations of TRS $\left(\mathrm{H}_{2} \mathrm{~S}, \mathrm{~S}^{0}, \mathrm{FeS}\right.$ and $\mathrm{FeS}_{2}$ ) at the $0-2 \mathrm{~cm}$ depth interval were 3 -fold higher at the farm site $\left(80 \pm 8.3 \mu \mathrm{mol} \mathrm{cm}{ }^{-3}\right)$ than at the reference site $\left(26 \pm 17 \mu \mathrm{mol} \mathrm{cm}{ }^{-3}\right)$ (Fig. 2J).

$$
\begin{aligned}
& \mathrm{CH}_{3} \mathrm{COO}^{-}+8 \mathrm{FeOOH}+3 \mathrm{H}_{2} \mathrm{O}= \\
& 2 \mathrm{HCO}_{3}{ }^{-}+8 \mathrm{Fe}^{2+}+15 \mathrm{OH}^{-} \\
& 3 \mathrm{H}_{2} \mathrm{~S}+4 \mathrm{FeOOH}=\mathrm{S}^{0}+\mathrm{S}_{2} \mathrm{O}_{3}{ }^{2-}+4 \mathrm{Fe}^{2+}+5 \mathrm{H}_{2} \mathrm{O} \\
& \mathrm{H}_{2} \mathrm{~S}+\mathrm{Fe}^{2+}=\mathrm{FeS}+2 \mathrm{H}^{+}
\end{aligned}
$$

\section{Bacterial communities associated with production and removal of reduced sulfur}

Phylogenetic analysis of the $d s r A$ functional gene and the 16S rRNA gene revealed that the sequences closely affiliated with Syntrophobacteraceae and Desulfobulbaceae predominated at both sites (Fig. 4, Table 3). Most members (e.g. Desulfacinum, Desulforhabdus and Thermodesulforhadus) in family Syn- 
Fig. 5. Phylogenetic relationships of epsilonproteobacterial clones obtained from the fish-farm sediments. The phylogenetic tree is based on the $16 \mathrm{~S}$ rRNA gene sequences. The tree was constructed using the neighbor-joining method with Aquifex pyrophilus. The clones from $0-1 \mathrm{~cm} \mathrm{(1)} \mathrm{and} \mathrm{1-2} \mathrm{cm}$ (2) depths at the farm (YF, red) and reference (YC, blue) sites are denoted in bold. Numbers in square brackets indicate the number of clones found in the clone libraries. GenBank accession numbers for each sequence are indicated in parentheses
Anaerobic marine sediments clone D30 (GQ249572)

86 YF1 B91 [8] (KC631485)

69 Uncultured epsilon proteobacterium clone 1b_13 (HE803939)

Uncultured bacterium clone SW-Apr-97 in seawater (HQ203960)

86 - 86 YC2 B39 [6] (KC631588)

YF2 B97 [37] (KC631508)

_ Amsterdam mud volcano sediment clone AMSMV-5-B2 (HQ588432)

_Uncultured Sulfurovum sp. clone 2B_324 in lagoon sediment (AM501822)

- Rimicaris exoculata in deep sea clone 15 (AJ515716)

78 Uncultured Sulfurovum sp. clone TNG01-97 (KF545067)

95 Guaymas basin hydrothermal vent sediments clone B01R002 (AY197375)

- YF2 B34 [3] (KC631497)

- Uncultured Sulfurovum sp. clone Richicolo-C10 in salmon farm (KP994481)

99 Mariculture sediment clone D30909 (JX193374)

-Dee[ sea sediment associated with whale falls clone 7mos_0dMF9 (GQ261802)

52 YF2 B99 [17] (KC631509)

YC1 B32 [9] (KC631527)

Sulfurovum aggregans (NR 126188)

Nankai Trough sediment clone NKB10 (AB013262)

- Sulfurovum riftiae (NR 149787)

76 Sulfurovum lithotrophicum (NR 024802)

Deep sea sediment related to whale falls clone 7mosod_F9 (AB197161)

$60 \quad$ YC2 B46 (KC631590)

89 - Mangrove sediment clone XME 15 (EF061977)

96 _-Uncultured Sulfurovum sp. clone 1_2 in ocean water (KF758583)

- Uncultured Sulfurovum sp. clone DVBSD_M292 (KF465256)

Rimicaris exoculata ectosymbiont(REU29081)

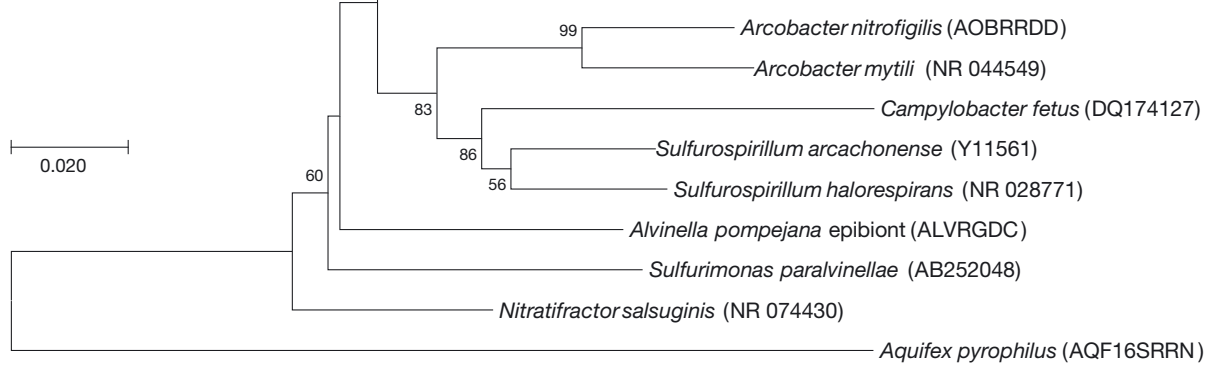

trophobacteraceae perform a complete oxidation of organic substrates, whereas the members of Syntrophobacter are known to be associated with an incomplete oxidation to produce acetate (Rosenberg et al. 2014). Due to the low similarity $(57-75 \%)$ with the cultured isolates in Fig. 4, it remains to be resolved if the uncultured Syntrophobacteraceae groups obtained in our dsrA gene analysis (Fig. 4) are directly responsible for the complete or incomplete oxidation of $\mathrm{C}_{\text {org }}$. However, the clones from the 16S rRNA gene sequence showed high similarity (> $95 \%$ ) with Desulfobulbus (Table 3), which is known to oxidize a broad range of substrates (e.g. propionate, alcohols and lactate) resulting from various fermentation pathways to produce acetate in anoxic freshwater and marine sediments (Lien et al. 1998, Pagani et al. 2011, Sorokin et al. 2012, Rosenberg et al. 2014). Because incomplete oxidizers can grow faster than complete oxidizers in natural sediments receiving pulses of rich organic material (Widdel 1988, also see Canfield et al. 2005), the Desulfobulbus-like bacterial communities in this study seem to be able to proliferate readily around the fish-farm sediments.

Despite the high SRR and $d s r A$ abundance, the depletion of sulfide at the $0-2 \mathrm{~cm}$ depth at the fish farm (Fig. 3A,B) remains to be explained in terms of which microorganisms are associated with the removal of sulfide. Interestingly, at the 1-2 cm depth interval of this sulfide mismatch layer, Epsilonproteobacteria closely affiliated with Sulfurovum lithotrophicum (similarity $>95 \%$ ), S. riftiae (similarity > $94 \%$ ) and $S$. aggregans (similarity $>95 \%$ ) composed the major fraction $(62.0 \%)$ of total sequences (Figs. 5 $\& 6$, Table 3). Similar results were reported in the 
sediments of salmon farms where Epsilonproteobacteria is a major bacterial group (Aranda et al. 2015), although the percentage (39\% of total clones) was lower than that reported in the present study. Both $S$. lithotrophicum and S. riftiae, isolated from the oxic-anoxic interface where sulfides meet oxygenated sea water, and the vent polychaete Riftia pachptila, respectively, are known to be chemolithoautotrophs using $\mathrm{S}^{0}$ or $\mathrm{S}_{2} \mathrm{O}_{3}{ }^{2-}$ as an electron donor and $\mathrm{O}_{2}$ or $\mathrm{NO}_{3}{ }^{-}$as an electron acceptor (Inagaki et al. 2004, Giovannelli et al. 2016) (Fig. 5). In this study, it is likely that the $\mathrm{S}^{0}$ or $\mathrm{S}_{2} \mathrm{O}_{3}{ }^{2-}$ was produced by the oxidation of $\mathrm{H}_{2} \mathrm{~S}$ coupled with the reduction of Fe(III) via Eq. (2) and served as electron donors for the Sulfurovum-like SOB that flourished in the sulfidemismatched zone where either $\mathrm{O}_{2}$ or $\mathrm{NO}_{3}{ }^{-}$is available as an electron acceptor. Unlike $S$. lithotrophicum and $S$. riftiae, $S$. aggregans uses $\mathrm{H}_{2}$ as an electron donor and $\mathrm{S}^{0}, \mathrm{~S}_{2} \mathrm{O}_{3}{ }^{2-}$ and $\mathrm{NO}_{3}{ }^{-}$as electron acceptors under more anoxic conditions (Mino et al.
2014). Thus, bacteria closely related to $S$. aggregans may play a significant role in the reduction of $\mathrm{S}^{0}$ and $\mathrm{S}_{2} \mathrm{O}_{3}{ }^{2-}$ in the $1-2 \mathrm{~cm}$ depth of fish-farm sediments.

In contrast to the Sulfurovum-like bacteria that thrived at the 1-2 cm depth, the clones that had high similarity (>95\%) with Thioalbus, Thioalkalivibrio, Thioalomonas, Thiohalobacter, Thiolapillus and Thioprofundum in Gammaproteobacteria occupied a major fraction (12-19\% of total clones) mostly at the 0 to $1 \mathrm{~cm}$ depth interval of both farm and reference sites (Fig. 6, Table 3). Both Sulfurovum and the members of Gammaproteobacteria are microaerophilic chemolithoautotrophic sulfur oxidizers (Sorokin et al. 2001, Park et al. 2011, Nunoura et al. 2014). Gammaproteobacteria have a kinetically advantageous energyproducing pathway when oxygen and reduced sulfur compounds are steadily supplied, whereas Epsilonproteobacteria have the metabolic versatility to adapt to transient environmental conditions where the shift from aerobic to anaerobic microbial communities oc-

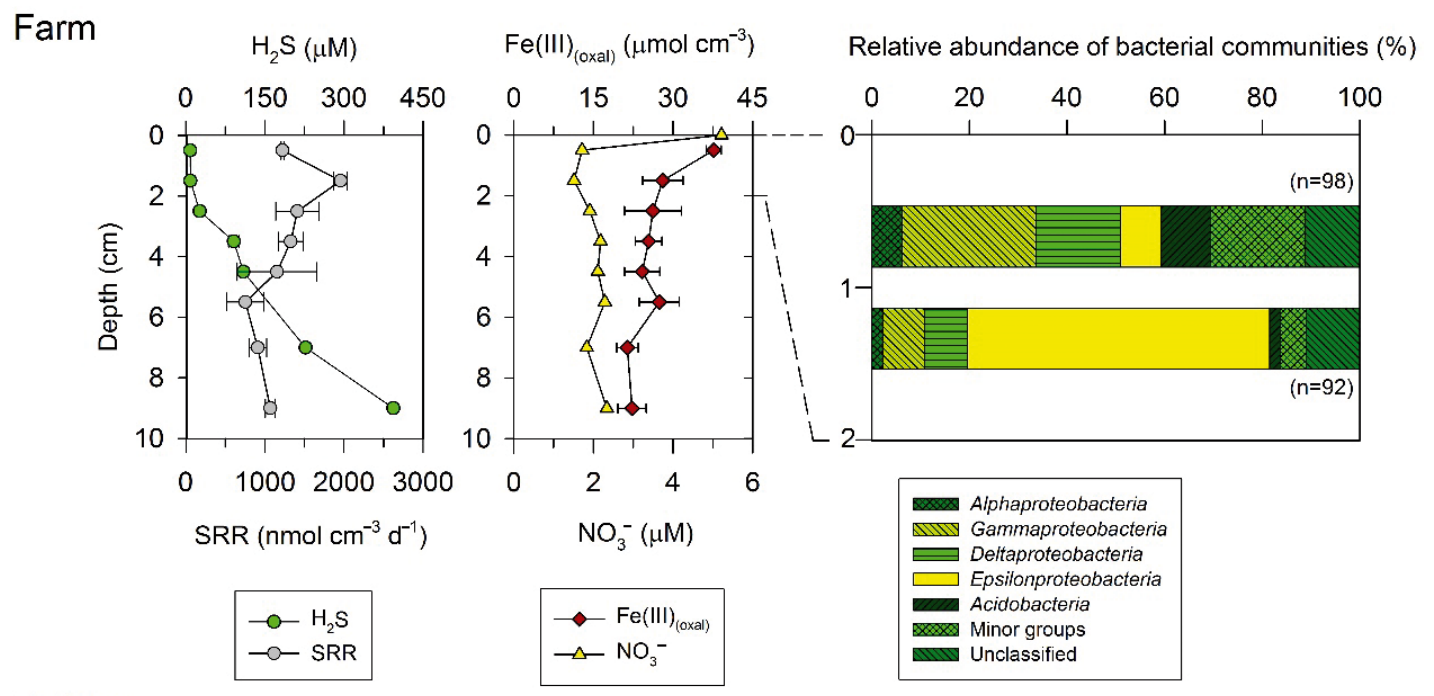

Reference
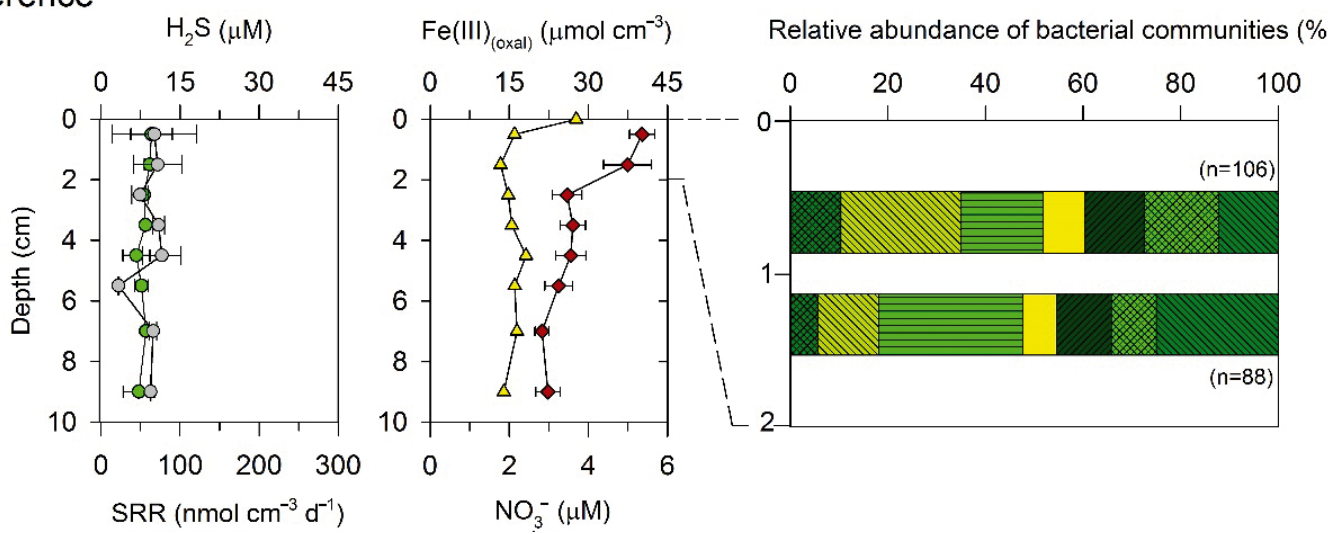

Fig. 6. Relative abundance of bacterial communities based on the 16S rRNA gene in the surface sediments (0-2 cm) associated with the vertical distribution of $\mathrm{H}_{2} \mathrm{~S}, \mathrm{NO}_{3}{ }^{-}, \mathrm{Fe}(\mathrm{III})_{\text {(oxal) }}$ and sulfate reduction rates (SRR). Bar represents the percentage of clone library composition represented by each group at the farm and reference sites 
curs (Yamamoto \& Takai 2011, Ihara et al. 2017). Consequently, our results strongly suggest that Sulfurovum-like bacteria in Epsilonproteobacteria play a significant ecological and biogeochemical role in the oxidation and reduction of reduced sulfur compounds in the highly sulfidic fish-farm sediments.

Acknowledgements. This study was supported by the 'National Institute of Fisheries Science (R2018054) and the Korean Long-term Marine Ecological Research (K-LTMER) program titled 'Long-term Change of Structure and Function in Marine Ecosystems' funded by the Korean Ministry of Oceans and Fisheries. A.C. was supported by the 'Global PhD Fellowship Program' through the National Research Foundation of Korea funded by the Ministry of Education.

\section{LITERATURE CITED}

Angermeyer A, Crosby SC, Huber JA (2016) Decoupled distance-decay patterns between dsrA and 16S rRNA genes among salt marsh sulfate-reducing bacteria. Environ Microbiol 18:75-86

Aranda CP, Valenzuela C, Matamala Y, Godoy FA, Aranda N (2015) Sulphur-cycling bacteria and ciliated protozoans in a Beggiatoaceae mat covering organically enriched sediments beneath a salmon farm in a southern Chilean fjord. Mar Poll Bull 100:270-278

Bissett A, Bowman J, Burke C (2006) Bacterial diversity in organically-enriched fish farm sediments. FEMS Microbiol Ecol 55:48-56

Asami H, Aida M, Watanabe K (2005) Accelerated sulfur cycle in coastal marine sediment beneath areas of intensive shellfish aquaculture. Appl Environ Microbiol 71: 2925-2933

Ashelford KE, Chuzhanova NA, Fry JC, Jones AJ, Weightman AJ (2005) At least 1 in 20 16S rRNA sequence records currently held in public repositories is estimated to contain substantial anomalies. Appl Environ Microbiol 71:7724-7736

Brooks KM, Mahnken CVW (2003) Interactions of Atlantic salmon in the Pacific Northwest environment II. Organic wastes. Fish Res 62:255-293

Campbell BJ, Jeanthon C, Kostka JE, Luther GW III, Cary SC (2001) Growth and phylogenetic properties of novel bacteria belonging to the epsilon subdivision of the Proteobacteria enriched from Alvinella pompejana and deep-sea hydrothermal vents. Appl Environ Microbiol $67: 4566-4572$

* Canfield DE, Thamdrup B (1996) Fate of elemental sulfur in an intertidal sediment. FEMS Microbiol Ecol 19:95-103

Canfield DE, Thamdrup B, Kristensen E (eds) (2005) The sulfur cycle. In: Aquatic geomicrobiology, Vol 48, 1st edn. Elsevier Academic Press, London

*astine SA, Bourne DG, Trott LA, Macinnon DA (2009) Sediment microbial community analysis: establishing impact of aquaculture on a tropical mangrove ecosystem. Aquaculture 287:91-98

Cho YS, Lee WC, Kim JB, Hong SJ, Kim HC, Kim CS (2013) Establishment of environmental assessment using sediment total organic carbon and macrobenthic polycheate community in shellfish farms. J Korean Soc Mar Environ Saf 19:430-438
Cho H, Hyun JH, You OR, Kim M and others (2017) Microbial community structure associated with biogeochemical processes in the sulfate-methane transition zone (SMTZ) of gas-hydrate-bearing sediment of the Ulleung Basin, East Sea. Geomicrobiol J 34:207-219

Cline JD (1969) Spectrophotometric determinations of hydrogen sulfide in natural waters. Limnol Oceanogr 14 : 454-458

米Dahlbäck B, Gunnarsson LÅH (1981) Sedimentation and sulfate reduction under a mussel culture. Mar Biol 63: 269-275

* de Rezende JR, Kjeldsen KU, Hubert CRJ, Finster K, Loy A, Jørgensen BB (2013) Dispersal of thermophilic Desulfotomaculum endospores into Baltic Sea sediments over thousands of years. ISME J 7:72-84

FAO (2010) The state of world fisheries and aquacultures 2010. FAO, Rome

FAO (2014) The state of world fisheries and aquacultures 2014. FAO, Rome

F Fossing H, Jørgensen BB (1989) Measurement of bacterial sulfate reduction in sediments: evaluation of a singlestep chromium reduction method. Biogeochemistry 8: 205-222

*Giloteaux L, Goñi-Urriza M, Duran R (2010) Nested PCR and new primers for analysis of sulfate-reducing bacteria in low-cell-biomass environments. Appl Environ Microbiol 76:2856-2865

* Giovannelli D, Chung M, Staley J, Starovoytov V, Le Bris N, Vetiani C (2016) Sulfuovum riftiae sp. von., a mesophilic thiosulfate-oxidizing, nitrate-reducing chemolithoautotrophic epsilonproteobacterium isolated from the tube of the deep-sea hydrothermal vent polychaete Riftia pachyptila. Int J Syst Evol Microbiol 66:2697-2701

Goffredi SK, Orphan VJ (2010) Bacterial community shifts in taxa and diversity in response to localized organic loading in the deep sea. Environ Microbiol 12:344-363

* Gray JS, Wu RS, Or YY (2002) Effects of hypoxia and organic enrichment on the coastal marine environment. Mar Ecol Prog Ser 238:249-279

Hansen HP, Koroleff F (1999) Determination of nutrients. In: Grasshoff K, Kremling K, Ehrhardt M (eds) Methods of seawater analysis, 3rd edn. Wiley-VCH, Weinheim, p 159-228

Hargrave BT (2010) Empirical relationships describing benthic impacts of salmon aquaculture. Aquacult Environ Interact 1:33-46

* Harrison BK, Zhang H, Berelson W, Orphan VJ (2009) Variations in archaeal and bacteria diversity associated with the sulfate-methane transition zone in continental margin sediments (Santa Barbara Basin, California). Appl Environ Microbiol 75:1487-1499

Heilskov AC, Alperin M, Holmer M (2006) Benthic fauna bio-irrigation effects on nutrient regeneration in fish farm sediments. J Exp Mar Biol Ecol 339:204-225

* Holmer M, Kristensen E (1992) Impact of marine fish cage farming on metabolism and sulfate reduction of underlying sediments. Mar Ecol Prog Ser 80:191-201

*Holmer M, Ahrensberg N, Jørgensen NP (2003) Impact of mussel dredging on sediment phosphorus dynamics in a eutrophic Danish fjord. Chem Ecol 19:343-361

Holmer M, Wildish D, Hargrave B (2005) Organic enrichment from marine finfish aquaculture and effects on sediment biogeochemical processes. In: Hargrave BT (ed) Environmental effects of marine finfish aquaculture. Springer, Berlin, p 181-206 
Hyun JH, Kim SH, Mok JS, Lee JS, An SU, Lee WC, Jung $\mathrm{RH}$ (2013) Impact of long-line aquaculture of Pacific oysters (Crassostrea gigas) on sulfate reduction and diffusive nutrient flux in the coastal sediments of JinhaeTongyeong, Korea. Mar Pollut Bull 74:187-198

Ihara H, Hori T, Aoyagi T, Takasaki M, Katayama Y (2017) Sulfur-oxidizing bacteria mediate microbial community succession and element cycling in launched marine sediment. Front Microbiol 8:152

Inagaki F, Takai K, Nealson KH, Horikoshi K (2004) Sulfurovum lithotrophicum gen. nov., sp. Nov., a novel sulfur-oxidizing chemoplithoautotroph within the $\varepsilon$-Proteobacteria isolated from Okinawa Trough hydrothermal sediments. Int J Syst Evol Microbiol 54:1477-1482

Jiang L, Zheng Y, Peng X, Zhou H, Zhang C, Xiao X, Wang F (2009) Vertical distribution and diversity of sulfate-reducing prokaryotes in the Pearl River estuarine sediments, Southern China. FEMS Microbiol Ecol 70:241-262

Jørgensen BB (1978) A comparison of methods of the quantification of bacterial sulfate reduction in coastal marine sediments: I. Measurement with radiotracer techniques. Geomicrobiol J 1:11-28

Jørgensen BB (2006) Bacteria and marine biogeochemistry, 2nd edn. In: Schulz HD, Zabel M (eds) Marine Geochemistry. Springer, Berlin, p 169-206

Jung RH, Seo IS, Choi BM, Choi M and others (2016) Community structure and health assessment of macrobenthic assemblages at spring and summer in Geoje-Hansan bay, Southern Coast of Korea. J Korean Soc Mar Environ Saf 22:27-41

Kaneko R, Hayashi T, Tanahashi M, Naganuma T (2007) Phylogenetic diversity and distribution of dissimilatory sulfite reductase genes from deep-sea sediment cores. Mar Biotechnol (NY) 9:429-436

Kawahara N, Shingematsu K, Miyadai T, Kondo R (2009) Comparison of bacterial communities in fish farm sediments along an organic enrichment gradient. Aquaculture 287:107-113

Kim B, Choi A, An S, Kim HC, Jung RH, Lee WC, Hyun JH (2011) Rates of sulfate reduction and iron reduction in the sediment associated with abalone aquaculture in the southern coastal waters of Korea. Ocean Polar Res 33: 435-445

Kondo R, Nedwell DB, Purdy KJ, Silva SQ (2004) Detection and enumeration of sulphate-reducing bacteria in estuarine sediments by competitive PCR. Geomicrobiol J 21: 145-157

Kondo R, Shigematsu K, Butani J (2008) Rapid enumeration of sulphate-reducing bacteria from aquatic environments using real-time PCR. Plankton Benthos Res 3:180-183

KKondo R, Shigematsu K, Kawahara N, Okamura T and others (2012a) Abundance of sulphate-reducing bacteria in fish farm sediments along the coast of Japan and South Korea. Fish Sci 78:123-131

Kondo R, Mori Y, Sakami T (2012b) Comparison of sulphatereducing bacterial communities in Japanese fish farm sediments with different levels of organic enrichment. Microbes Environ 27:193-199

Kutti T, Erivik A, Hansen PK (2007) Effects of organic effluents from a salmon farm on a fjord system. I. Vertical export and dispersal processes. Aquaculture 262:367-381

Lee JS, Jung RH, Kim KH, Kwon JN and others (2004) An evaluation of the environmental effects of marine cage fish farms: I. Estimation of impact region and organic carbon cycling in sediment using sediment oxygen con- sumption rates and macrozoobenthos. J Kor Soc Oceanogr 9:30-39

* Lee JS, Kim YT, Shin KH, Hyun JH, Kim SY (2011) Benthic nutrient fluxes at longline sea squirt and oyster aquaculture farms and their role in coastal ecosystems. Aquacult Int 19:931-944

พ Leloup J, Fossing H, Kohls K, Holmkvist L, Borowski C, Jørgensen BB (2009) Sulfate-reducing bacteria in marine sediment (Aarhus Baym Denmark): abundance and diversity related to geochemical zonation. Environ Microbiol 11:1278-1291

* Li J, Li F, Yu S, Qin S, Wang G (2013) Impacts of mariculture on the diversity of bacterial communities within intertidal sediments in the northeast of China. Microb Ecol 66: 861-870

Lien T, Madsen M, Steen IH, Gjerdevik K (1998) Desulfobulbus rhabdoformis sp. nov., a sulfate reducer from a wateroil separation system. Int J Syst Bacteriol 48:469-474

Liu XZ, Zhang LM, Prosser JI, He JZ (2009) Abundance and community structure of sulfate reducing prokaryotes in a paddy soil of southern China under different fertilization regimes. Soil Biol Biochem 41:687-694

Macleod CK, Moltschaniwskyj NA, Crawford CM (2008) Ecological and functional changes associated with longterm recovery from organic enrichment. Mar Ecol Prog Ser 365:17-24

*Mino S, Kudo H, Arai T, Sawabe T, Takai K, Nakagawa S (2014) Sulfurovum aggregans sp. nov., a hydrogen-oxidizing, thiosulfate-reducing chemolithoautotroph within the Epsilonproteobacteria isolated from a deep-sea hydrothermal vent chimney, and an emended description of the genus Sulfurovum. Int J Syst Evol Microbiol 64:3195-3201

MOF (Ministry of Oceans and Fisheries) (2016) Establishment of criteria for fishery environments. MOF, Sejong (in Korean)

NIFS (National Institute of Fisheries Science) (2007) Standard manual of black rockfish culture. NIFS, Busan (in Korean)

NIFS (2010) Survey of fishery environment. NIFS, Busan (in Korean)

NIFS (2013) Assessment of fishery environment and establishment of guidelines. NIFS, Busan (in Korean)

Nunoura T, Takaki Y, Kazama H, Kakuta J and others (2014) Physiological and genomic features of a novel sulfuroxidizing Gammaproteobacteriaum belonging to a previously uncultivated symbiotic lineage isolated from hydrothermal vent. PLOS ONE 9:e104959

Pachiadaki MG, Kallionaki A, Dählmann A, De Lange GJ, Kormas KA (2011) Diversity and spatial distribution of prokaryotic communities along a sediment vertical profile of a deep-sea mud volcano. Microb Ecol 62:655-668

* Pagani I, Lapidus A, Nolan M, Lucas S and others (2011) Complete genome sequence of Desulfobulbus propionicus type strain $\left(1 \mathrm{pr}^{\mathrm{T}}\right)$. Stand Genomic Sci 4:100-110

* Park SJ, Pham VH, Jung MY, Kim SJ, Kim JG, Roh DH, Rhee SK (2011) Thioalbus denitrificans gen. nov., sp. nov., a chemolithoautotrophic sulfur-oxidizing gammaproteobacterium, isolated from marine sediment. Int J Syst Evol Microbiol 61:2045-2051

Phillips EJP, Lovley DR (1987) Determination of Fe(III) and $\mathrm{Fe}(\mathrm{II})$ in oxalate extracts of sediments. Soil Sci Soc Am J 51:938-941

Rho S, An NH, Ahn DH, Lee KH, Lee DH, Jahng D (2005) PCR-T-RFLP analyses of bacterial communities in acti- 
vated sludges in the aeration tanks of domestic and industrial wastewater treatment plants. J Microbiol Biotechnol 15:287-295

Rosenberg E, Delong EF, Lory S, Stackebrandt E, Thompson F (2014) I. Deltaproteobacteria. In: Rosenberg E, Delong F, Lory S, Stackebrandt E, Thompson F (eds) The prokaryotes, Deltaproteobacteria and Epsilonproteobacteria, 4th edn. Springer, New York, NY, p 1-303

Schloss PD, Westcott SL, Thomas R, Hall JR and others (2009) Introducing mother: open source, platform-independent, community-supported software for describing and comparing microbial communities. Appl Environ Microbiol 75:7537-7541

Sorokin DY, Lysenko AM, Mityushina LL, Tourova TP and others (2001) Thioalkalimicrobium sibiricum, Thioalkalimicrobium aerophilum gen. nov., sp. nov., and Thioalkalivibrio versutus, Thioalkalivibrio nitratis, Thioalkalivibrio denitrificans gen. nov., sp. nov., new obligately alkaliphilic and obligately chemolithoautotrophic sulfuroxidizing bacteria from soda lakes. Int J Syst Evol Microbiol 51:565-580

Sorokin DY, Tourova TP, Panteleeva A, Muyzer G (2012) Desulfonatronobacter acidivorans gen. nov., sp. nov. and Desulfobulbus alkaliphilus sp. nov., haloalkaliphilic heterotrophic sulfate-reducing bacteria from soda lakes. Int J Syst Evol Microbiol 62:2107-2113

Stookey LL (1970) Ferrozine-a new spectrophotometric reagent for iron. Anal Chem 42:779-781

Strain PM, Hargrave BT (2005) Salmon aquaculture, nutrient fluxes and ecosystem processes in Southwestern New Brunswick. In: Hargrave BT (ed) Environmental effects of marine finfish aquaculture. Springer, Berlin, p 29-57

Thamdrup B, Canfield DE (1996) Pathways of carbon oxidation in continental margin sediments off central Chile. Limnol Oceanogr 41:1629-1650

Editorial responsibility: Marianne Holmer, Odense, Denmark
Thamdrup B, Finster K, Hansen JW, Bak F (1993) Bacterial disproportionation of elemental sulfur coupled to chemical reduction of iron or manganese. Appl Environ Microbiol 59:101-108

Valdemarsen T, Hansen PK, Ervik A, Bannister RJ (2015) Impact of deep-water fish farms on benthic macrofauna communities under different hydrodynamic conditions. Mar Pollut Bull 101:776-783

*Vezzulli L, Chelossi E, Riccardi G, Fabiano M (2002) Bacterial community structure and activity in fish farm sediments of the Ligurian Sea (Western Mediterranean). Aquacult Int 10:123-141

*Wagner M, Roger AJ, Flax JL, Brussequ GA, Stahl DA (1998) Phylogeny of dissimilatory sulfite reductase supports an early origin of sulfate respiration. J Bacteriol 180:2975-2982

Widdel F (1988) Microbiology and ecology of sulfate-and sulfur-reducing bacteria. In: Zehnder AJB (ed) Biology of anaerobic organisms. John Wiley, New York, NY, p 469-585

Y Yamamoto M, Takai K (2011) Sulfur metabolisms in epsilonand gamma-proteobacteria in deep-sea hydrothermal fields. Front Microbiol 2:192

* Yokoyama H (2003) Environmental quality criteria for fish farms in Japan. Aquaculture 226:45-56

Yoon SP, Jung RH, Kim YJ, Hong SJ, Oh HT, Lee WC (2009) Spatio-temporal changes in macrobenthic community structure and benthic environment at an intensive oyster culturing ground in Geoje-Hansan Bay, Korea. J Kor Soc Oceanogr 14:213-229

* Zhang W, Song L, Ki JS, Lau CL, Li XD, Qian PY (2008) Microbial diversity in polluted harbor sediments II: sulfate-reducing bacterial community assessment using terminal restriction fragment length polymorphism and clone library of $d s r A B$ gene. Estuar Coast Shelf Sci 76: 682-691

Submitted: November 6, 2017; Accepted: July 31, 2018

Proofs received from author(s): September 11, 2018 